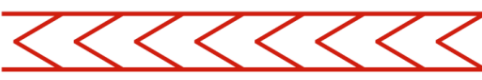

\title{
O PALCO E A ESTRADA: O LUGAR DA PERFORMANCE NO ROMANCE DE DOM PANTERO NO PALCO DOS PECADORES, DE ARIANO SUASSUNA
}

\section{Ester Suassuna Simões ${ }^{1}$}

Resumo: Ariano Suassuna (1927-2014) passou os últimos 30 anos de sua vida trabalhando no livro que chamava de "síntese" de toda a sua obra. O Romance de Dom Pantero no Palco dos Pecadores só veio a ser publicado postumamente em dezembro de 2017. Especula-se que um dos fatores que tornou longo o processo de escrita foi a busca pelo formato que permitisse a síntese almejada. Baseando-se em textos de autores como Azevedo (2007), Klinger (2008), Newton Junior (2017), Ravetti (2002), e Zumthor (2014), este trabalho investiga a importância da performance como solução para o projeto de síntese buscado por Suassuna em seu romance. Iniciamos por desvendar a figura do Dom Pantero, os heterônimos presentes no romance e o projeto da "ilumiara" de Suassuna para, em seguida, contextualizar o desenvolvimento de suas aulas-espetáculo, apresentações em que se fundiam duas de suas figuras performáticas: o palhaço e o professor. A importância do contar sertanejo e também a performance no objeto livro do Romance de Dom Pantero são em seguida abordadas.

PALAVRAS-CHAVE: Ariano Suassuna; Dom Pantero; Aula-espetáculo; Performance

\section{THE STAGE AND THE ROAD: THE PLACE OF PERFORMANCE IN ROMANCE DE DOM PANTERO NO PALCO DOS PECADORES BY ARIANO SUASSUNA}

ABSTRACT: Ariano Suassuna (1927-2014) spent the last 30 years of his life working on the book he referred to as all of his work's "synthesis". Romance de Dom Pantero no Palco dos Pecadores (The novel of Dom Pantero at the sinners' stage) was published on December 2017, after the author's death. One of the factors that may have helped to delay the process of writing it was the search for the right format that allowed the achievement of the wanted synthesis. This paper aims to investigate the importance of performance as the solution for Suassuna's synthesis project using as sources the works of authors such as Azevedo (2007), Klinger (2008), Newton Junior (2017), Ravetti (2002), and Zumthor (2014). We begin by unveiling the mask of Dom Pantero, the heteronyms present on the book and Suassuna's 'ilumiara'. Then we contextualize the development of his aulas-espetáculo (show classes) which were performances in which he used to merge two performatic figures: the clown and the teacher. The importance of story-telling in Suassuna's region and also the presence of performance at the printed book of Romance de Dom Pantero will then be approached.

KeYwordS: Ariano Suassuna; Dom Pantero; Show-Classes; Performance

\section{Introdução - Ariano Suassuna, Dom Pantero e as suas ilumiaras}

Em dezembro de 2017, saiu, pela Editora Nova Fronteira, a edição póstuma do livro inédito Romance de Dom Pantero no Palco dos Pecadores, do escritor paraibano

\footnotetext{
${ }^{1}$ Doutoranda no Programa de Pós-Graduação em Ciência da Literatura da UFRJ, bolsista Capes. Mestra em Letras - área de concentração Teoria da Literatura - pela UFPE. E-mail: ssimoes.ester@gmail.com
} 

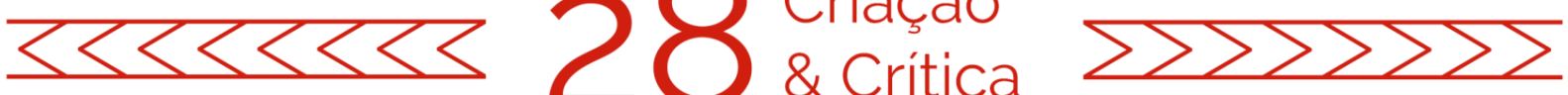

Ariano Suassuna, que havia se encantado ${ }^{2}$ no dia 23 de julho de 2014. Suassuna passara pelo menos trinta anos construindo essa obra, a qual se referia como "síntese" de tudo o que já havia produzido.

O livro, que tem cerca de mil páginas, foi publicado em dois volumes: Livro I - O Jumento Sedutor; Livro II - O Palhaço Tetrafônico. Cada livro contém quatro cartas. No Livro I: PRELÚDIO - O Protagonista Insano; REPENTE - O Antagonista Possesso; CHAMADA - O Chabino Desamado; GALOPE - A Trupe Errante da Estrada. No Livro II: PRELÚDIO - O Rapsodo Agonizante; REPENTE - O Bufão Apocalíptico; TOCATA - O Caprípede Castanho; FUGA - A Persona do Poieta.

Todas as cartas são assinadas por Dom Pantero do Espírito Santo e endereçadas aos "Nobres Cavaleiros e Belas Damas da Pedra do Reino". Dom Pantero é uma das máscaras utilizadas por Antero Savedra, um "Rei-de-vidrilho, Poeta-frustrado, Profetaextravioso, Ator-por-acaso, Mágico-amador, Palhaço-de-suporte e Viajante-imaginário" (SUASSUNA, 2017b, p. 23). Antero Savedra é um dos muitos heterônimos "A.S." que aparecem na narrativa. Ele é sobrinho do ensaísta Antero Schabino e irmão do dramaturgo Adriel Soares, do poeta Altino Sotero e do romancista Auro Schabino. Vejamos um trecho do romance em que Antero se apresenta:

\section{DOM PANTERO}

Chamo-me Antero Savedra, nobres Cavaleiros e belas Damas da Pedra do Reino; e, como Altino, Auro e Adriel, sou filho do Cavaleiro - João Canuto Schabino de Savedra Jaúna - e de sua Mulher e prima, Maria Carlota Sotero Veiga Schabino de Savedra. Mas, do ponto de vista da nossa formação intelectual, fomos educados por nosso Tio, Antero Schabino Paulo Antero Soares da Veiga Schabino de Savedra -, irmão de nossa Mãe (...). (SUASSUNA, 2017b, p. 55.)

Em outro momento de apresentação, Antero Savedra afirma que a sua família é marcada por quatro "acontecimentos terríveis": o assassinato de seu pai, João Canuto, com um tiro nas costas no Riacho de Elo em 9 de outubro de 1930, o suicídio de seu irmão Mauro, em 6 de outubro de 1970, e os assassinatos de seus irmãos Auro e Adriel.

As duas datas referidas podem ser diretamente associadas a fatos trágicos que marcaram a família Suassuna: em 9 de outubro de 1930, o pai de Ariano, João Suassuna, foi assassinado com um tiro nas costas na Rua Riachuelo, no bairro da Lapa, cidade do Rio de Janeiro. Ele era deputado federal e estava na capital para se defender, pois havia sido injustamente acusado de ter participado do crime cometido pelo primo de sua esposa, João Dantas.

Dantas matara o então presidente da Paraíba, João Pessoa, e, naquele mesmo ano, também foi assassinado, na cadeia, no dia 6 de outubro. Foi também no dia 6 de outubro de 2010 que Joaquim, filho mais velho de Ariano Suassuna, tirou a própria vida. As marcas de sangue da história da família Suassuna se encontram, portanto, também

2 Escolhemos dizer como disse João Guimarães Rosa (1967), em seu discurso de posse na Academia Brasileira de Letras: "as pessoas não morrem, ficam encantadas". 

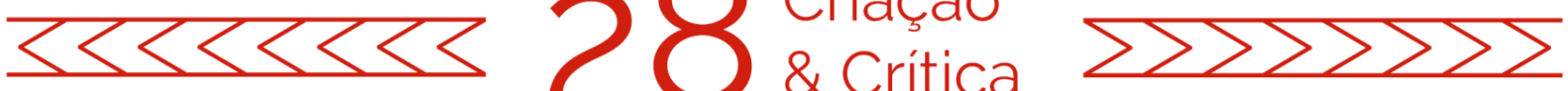

nas famílias Savedra e Schabino da literatura. No plano ficcional e no plano biográfico, aqueles "acontecimentos terríveis" se tornaram guias para a criação artística.

Assim, como forma de revolta contra o horror do assassinato do cunhado, Antero Schabino, o mestre e tio de Antero Savedra, propõe aos sobrinhos a criação de uma "Grande Obra", A llumiara. Na literatura, como na vida, a rejeição familiar pela violência física resulta em uma busca da vingança pela arte. Mas, ainda que muito talentosos, os irmãos de Dom Pantero não conseguem atingir esse objetivo em vida:

(...) meu Tio, Mestre e Padrinho Antero Schabino já tinha morrido, assim como meus irmãos Altino, Adriel e Auro. Nenhum deles fizera "a grande Obra" que nos fora proposta por Tio Antero em 1937. Entretanto, cada um deixara uma Obra menor e incompleta: Altino, ajudado por nós, fizera $O$ Pasto Incendiado; Auro, o Romance d'A Pedra do Reino; Tio Antero, A Onça Malhada; Adriel, o Auto d'A Misericordiosa e as outras peças cômicas que compunham suas Comédias Exemplares (nome a elas atribuído por Aderbal Freire Filho); se eu conseguisse fundir tudo numa Obra só, estaria pronta $A$ Ilumiara, com uma Poesia que era uma versão pessoal e recriada minha do Eu; com outra versão em Prosa d'A Pedra do Reino (que seria o equivalente "savédrico" de Os Sertões); e finalmente com o riso despedaçado pelo amor ao Brasil presente no Triste Fim de Policarpo Quaresma. (SUASSUNA, 2017b, pp. 95-96).

Os heterônimos "A.S." começam a se revelar. Representam as muitas vozes de Ariano Suassuna, nos diversos caminhos artísticos em que se aventurou: a poesia, representada no título de sua coletânea de poemas que nunca chegou a ser publicada isoladamente, O Pasto Incendiado; o romance, melhor executado n'A Pedra do Reino; o ensaio, aspecto da obra de Suassuna ainda pouco explorado pela crítica, aqui representado por título que faz alusão à tese de livre docência defendida pelo autor, "A Onça Castanha e a Ilha Brasil" (1976); e, finalmente, representados por um título que alude ao Auto da Compadecida, os textos teatrais de comédia. A Ilumiara seria, então, a grande síntese que Suassuna, como também Dom Pantero, buscava para transformar a sua Grande Obra em marco.

As interrelações entre vida e obra de Suassuna, não só as que já referenciamos aqui, mas as muitas outras que preenchem a narrativa, aproximam o Romance de Dom Pantero ao comentário que Luciene Azevedo faz em seu artigo sobre autoria e performance na literatura contemporânea: "as maneiras pelas quais o texto aponta para a figura do autor já nascem marcadas pelo arranjo indecidível entre vida e ficção, experiência real, do autor, e a composição distanciada dos papéis, personagens-tipo" (AZEVEDO, 2007, p. 137). A partir do mesmo artigo, outra aproximação pode ser feita no que tange a questão da performance, eixo central deste nosso trabalho. $O$ trecho nos parece especialmente relevante para pensar o caminho da polifonia aberto pela presença dos heterônimos "A.S." no romance:

nossa hipótese é que a performance narrativa é tanto uma instância que baralha a correspondência entre o vivido e o inventado, confundindo o 

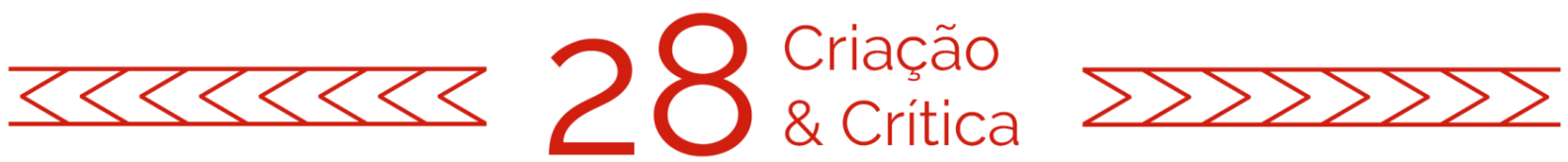

enredo ficcional com informações biográficas, como uma estratégia capaz de assegurar ao narrador assumir uma pluralidade de vozes. (AZEVEDO, 2007, p. 138)

O trecho do romance que transcrevemos acima é seguido de uma passagem em que essas duas faces da narrativa performática são exemplificadas. Nele, através das vozes de duas máscaras que assumem a figura desse autor/performer em palco, comenta-se a importância de um documentário que existe, em nosso plano, sob o título "Ariano: Suassunas":

\section{DOM PANTERO}

(...) Outra coisa que me ajudou em minha busca foi, já nos últimos anos, um Vídeo feito por Claudio Brito e intitulado Antero: Savedras, com depoimentos dados a meu respeito por minha irmã Afra Cantapedra, e pelos sobrinhos e filhos-adotivos que eu herdara de Adriel depois de sua morte. (...) E, mais importante do que tudo: no Vídeo, com sua argúcia habitual, Carlos de Souza Lima mostrava que, sendo meu Pai um Rei destronado, todo o meu trabalho no campo da Arte tinha como objetivo principal recolocá-lo no Trono.

\section{DOM PARIBO SALLEMAS}

Só havia um inconveniente na inclusão de tais Vídeos n'A llumiara: é que seus Autores (não sei se por implicância ou por qualquer outra razão) teimavam em tratar nosso Mestre não por Mariano Jaúna ou Antero Savedra, mas sim por um terceiro e estranho nome, cujo objetivo era reforçar a campanha de silêncio de que tinham resolvido obscurecer o sucesso do Antero Savedra verdadeiro.

De qualquer maneira - e fossem quais fossem as confusões e incompreensões que tal fato iria causar -, nosso Mestre terminou optando por incluir os Vídeos aqui porque somente com eles ficaria evidenciado o caráter musical, poético, dançarino, teatral e vídeo-cinematoGráfico d'A Ilumiara (SUASSUNA, 2017b, p. 96)

As "confusões e incompreensões" são, claro, parte do jogo performático. Cada leitor terá mais ou menos acesso às pistas biográficas ou referências, a depender do conhecimento prévio de outras obras do autor, mas no geral, as máscaras são eficazes em construir essa pluralidade de vozes de que falava Azevedo. A inclusão, no romance, de citações de vários estudiosos que escreveram sobre a obra de Suassuna (no caso do trecho transcrito, Carlos Newton Júnior e Claudio Brito) também revela um controle na construção dessa figura do autor.

Também os seguintes elementos que Graciela Ravetti associa ao que chama de narrativa performática parecem fazer sentido se relacionados às estratégias utilizadas por Suassuna em seu Romance Dom Pantero no palco dos Pecadores:

A exposição radical do si-mesmo, do sujeito enunciador assim como do local de enunciação; a recuperação de comportamentos renunciados ou 

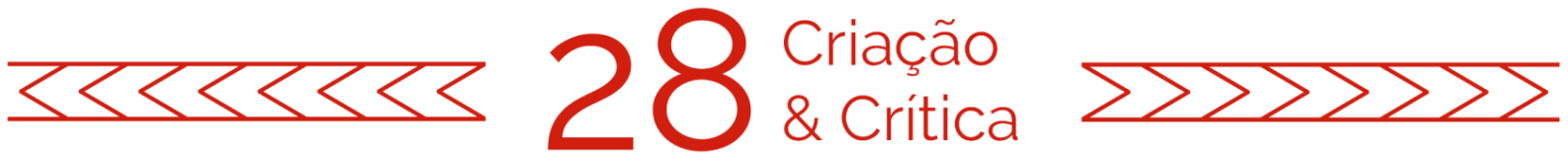

recalcados; a exibição de rituais íntimos; a encenação de situações da autobiografia, a representação das identidades como um trabalho de constante restauração, sempre inacabado, entre outros (RAVETTI, 2002, p. 47).

Mais adiante, trataremos com mais detalhe da construção dessa performance narrativa. Para tanto, achamos necessário inicialmente contextualizar melhor esse projeto de síntese almejado por Suassuna, através de uma introdução ao neologismo "ilumiara", criado por ele e central em sua obra. O escritor começou usando esse termo para designar os anfiteatros ancestrais que enxergava nos conjuntos de lajedos brasileiros em cujo centro há uma "itaquatiara".

As itaquatiaras são monumentos ancestrais em pedra insculpidas ou pintadas e normalmente feitos perto de córregos de água, a exemplo da Pedra do Ingá, na Paraíba. Suassuna identificava neles a potência de lugares que unem espiritualidade e arte. Uma descrição dessa primeira maneira de uso da palavra "ilumiara" está no seguinte trecho, de uma artigo originalmente publicado na década de 1970:

llumiaras são anfiteatros ou conjuntos-de-lajedos, insculpidos ou pintados há milhares de anos pelos antepassados dos índios Carirys no sertão do Nordeste brasileiro, e que, como "A Pedra do Ingá", na Paraíba, foram lugares de cultos. Por isso, normalmente têm como núcleo uma Itaquatiara, isto é, um Monólito-central, lavrado por baixos-relevos ou decorados por pinturas rupestres. (SUASSUNA, 2008, p.253)

Entre os anos de 1995 e 1998, quando o governador de Pernambuco era Miguel Arraes, Suassuna foi secretário de cultura do estado e promoveu a criação de espaços culturais que também chamou de "ilumiaras". Para esse mandato, Suassuna elaborou o "Projeto Cultural Pernambuco - Brasil", documento que apresentava os princípios e ações que regeriam sua atuação no governo.

Havia uma recente portaria que reforçava a necessidade da interiorização dos centros de cultura do estado, tentativa de diminuir a disparidade de investimentos em cultura nas diferentes regiões de Pernambuco. O texto do projeto aponta que, até aquele momento, só havia sido feita uma tímida tentativa de atingir esse objetivo com o Museu do Barro, em Caruaru, e que os centros culturais tendiam a ser grandes obras arquitetônicas de manutenção difícil. A solução idealizada por Ariano envolve as ilumiaras que enxergava no estado:

nossa ideia é partir de locais e grupos comunitários onde o próprio povo tenha organizado atividades ligadas às artes (...). Em nosso entender, os locais onde essas artes são praticadas é que são os verdadeiros centros culturais. Deles podemos partir para a criação de um centro real, barato, possível e que, ao mesmo tempo, corresponda à verdade profunda do nosso povo, o qual se encarregará, ele mesmo, de manter vivo e atuante o centro cultural que se originou do seu. É necessário, porém, ficarmos atentos para que a oficialização e a burocracia não prejudiquem, ou mesmo sufoquem, a beleza e a verdade da criação popular. Foi com todas 

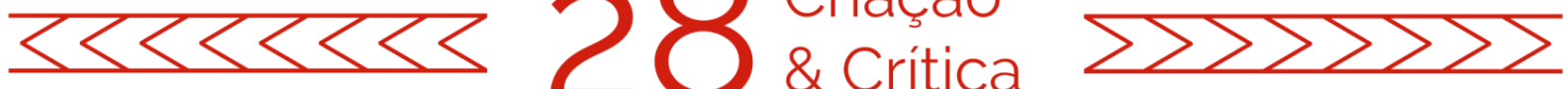

estas ideias como guias que se imaginou aliar os Centros Intermunicipais da Cultura às "Ilumiaras". (CAMPELO FILHO et al., 1995, p. 17)

A partir desse projeto, duas ilumiaras foram construídas no estado de Pernambuco: a llumiara Zumbi e a llumiara Pedra do Reino. A llumiara Zumbi fica na sede do Maracatu Piaba de Ouro, do grande Mestre Salustiano e sua família, no município de Olinda. O espaço é como um grande anfiteatro ornado com murais de pedra calcária que representam entidades das religiões afro-brasileiras.

A llumiara Pedra do Reino foi feita na Pedra Bonita, em São José do Belmonte, sertão de Pernambuco, cuja história inspirou o célebre romance. Aos pés da Pedra, foram erguidos doze santos e profetas idealizados por Ariano e executados em pedra pelo artista Arnaldo Barbosa. São esculturas de cerca de três metros, que compõem um místico cenário diante das pedras tão marcadas pela memória do sangue que as cobriu. O local serve de palco para diversos eventos culturais promovidos sobretudo pela Associação Cultural Pedra do Reino, fundada em março de 1995.

Mas não se encerram aqui as possibilidades do neologismo "ilumiara". Aos poucos, Suassuna começou a ampliar o alcance dessa palavra, usando-a para

identificar conjuntos artísticos os mais diversos, realizados em todos os tempos e também lugares (acrescentamos agora), que pudessem ser vistos como símbolos da força criadora de um povo ou espaços de celebração da sua cultura. Na visão de Suassuna, até mesmo certos livros, como A Divina Comédia e o Dom Quixote, poderiam ser classificados como ilumiaras, pela capacidade de sintetizarem os anseios universais do homem a partir de realidades locais e pelo vínculo que mantém com a tradição (NEWTON JÚNIOR, 2017, p. 12)

É nesse espírito que o escritor começa, então, a chamar de "ilumiara" o conjunto da sua própria obra. Ao longo dos anos, foi modificando edições de textos já publicados para que eles passassem a integrar um conjunto uno. Isso significou a mudança de cenário de algumas peças, mudanças em nomes de personagens, todo tipo de alterações que resultassem na integração entre as obras.

A página de abertura do Romance d'A Pedra do Reino, por exemplo, apresenta os seguintes dizeres em sua edição mais recente: "A llumiara - Romance d'A Pedra do Reino e o Príncipe do Vai-e-Volta - Airesiana Brasileira em Fá-Maior - Introdução ao 'Romance de Dom Pantero no palco dos Pecadores'” (SUASSUNA, 2017a, p. 29). O leitor e o pesquisador que se interessarem por esse romance já estão, portanto, avisados desde o princípio: cada obra de Suassuna é apenas uma peça de um grande painel artístico.

Ao nomear esse grande painel "ilumiara", Suassuna não só não se afasta dos outros usos de seu neologismo, como termina por revelar como pensava a sua obra:

como um marco do Brasil verdadeiro e profundo, que apontasse, para o nosso povo, um novo caminho a seguir, mais justo e fraterno, do ponto de vista social, do que o que trilhamos até agora; e mais belo e original do que 

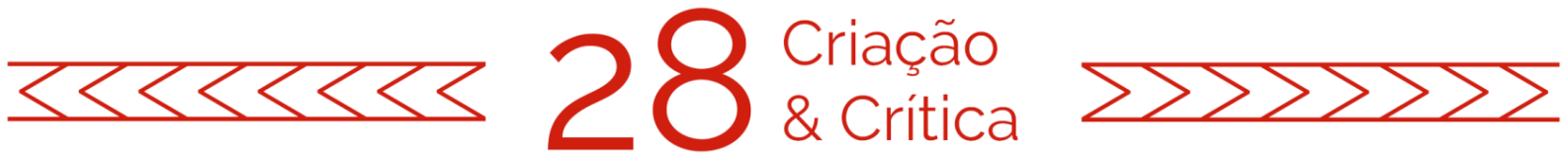

o caminho da vulgaridade, da descaracterização e do mau gosto, apontado pela massificação cultural e pelos apóstolos da globalização. (NEWTON JÚNIOR, 2017, p.13)

É importante perceber esse caráter sistêmico da obra de Suassuna. Tudo o que produziu compõe uma única grande obra de arte total. $O$ desejo de síntese que a escrita do Romance de Dom Pantero apontou se faz presente na visão totalizante que o escritor impunha em suas ações em todos os campos artísticos em que atuou. As novas edições já citadas apontavam para a necessidade de ler tudo o que ele escreveu como parte de um conjunto.

Antero Savedra, o personagem/heterônimo de que falávamos anteriormente, partilha com Ariano Suassuna o desejo de síntese na busca da construção da sua própria ilumiara:

Fiel ao sonho da minha juventude, venho fazendo o que posso e considerando cada Poema, cada Peça, cada Romance, cada Ensaio que consigo levantar como "um Caco" semelhante aos do genial Arquiteto popular que foi Gabriel Joaquim dos Santos: aos poucos, cada um deles iria se juntar ao todo que é A llumiara. (SUASSUNA, 2017b, p. 32)

O que atrapalhava a jornada de Savedra rumo à realização de seu imenso projeto era uma aparente falta de talento na escrita quando comparado aos seus irmãos. De qualquer forma, estava determinado a ser, ele mesmo, o grande autor da Grande Obra idealizada e desejada por seu mestre e tio. Terminou encontrando no palco, como encenador, a chave de suas potencialidades. Ele orquestra os textos e as citações de seus irmãos, do seu tio, dos mestres que admira (todos apresentados como integrantes de sua família, a exemplo de Miguel de Cervantes Schabino de Savedra) em um único e enorme diálogo - aqui está, novamente, a busca pela grande síntese. E aqui está também novamente a pluralidade de vozes e máscaras que compõem criação, pela performance, desse autor personagem:

A performance pode ser definida, então, como como repetição estilizada, como citação. A performance narrativa pode citar não apenas a ideia tradicional do autor como fonte do seu texto a fim de desmascará-la como uma condição fantasmática, como também pode citar outras vozes, travestir-se de máscaras, atuando em todo tipo de cena. Assim, o modo de atuação da performance implica não apenas a 'imitação' de uma pretensa autenticidade autoral, mas também seu deslocamento e ressignificação. (AZEVEDO, 2007, p.139)

Carlos Newton Júnior, grande estudioso da obra de Suassuna, acredita que havia, por parte do escritor, receio de repetir, em seu livro "novo" que viria ser o Dom Pantero, a voz de Quaderna, narrador da Pedra do Reino. Essa teria sido uma das razões para que o processo de escrita durasse tanto tempo. Foi na experiência das aulas-espetáculo, e, portanto, na performance pelo contar, na presença em palco, que ele e Antero Savedra (transfigurado em Dom Pantero) encontraram a saída para o problema: 

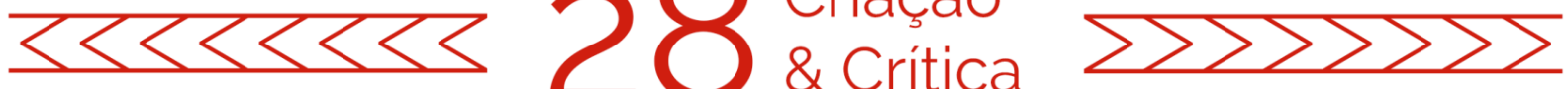

apresentado sob a forma de cartas, publicadas em um suplemento de jornal, o romance é na verdade um extenso diálogo do qual participam vários personagens. Ao longo deste diálogo, conduzido, em última instância, por dom Pantero, a trama do romance vai sendo tecida através da recitação de poemas, da encenação de espetáculos de música, dança e teatro, da discussão de teses filosóficas etc. (NEWTON JÚNIOR, 2014).

Dom Pantero é o "Protagonista Insano" e Quaderna o "Antagonista Possesso" d'A Ilumiara, que vai sendo construída a partir das saídas de Antero Savedra e das "AulasEspetaculosas" que performou com a máscara de Dom Pantero, nos dois elementoschave da superação da dor advinda dos acontecimentos terríveis, o Palco e a Estrada:

Ora, uma vez meu Tio, Mestre e Padrinho Antero Schabino afirmara que nós, Savedras, éramos "uma família trágica, como a dos Átridas". Por isso A llumiara é uma espécie de Orestíada, narrada, não por Ésquilo, mas sim por aquele que, na trama, seria um outro Orestes ou um novo Hamlet (ambos filhos de Pai assassinado, de um Rei assassinado). Mas este "Hamlet" acertaria a vencer sua dor no Palco e na Estrada, por meio das Armas que Deus Ihe concedeu - "o galope do Sonho", do Rei, e "o Riso a cavalo", do Palhaço. (SUASSUNA, 2017b, p.51)

A seguir, trataremos de quais maneiras a performance possibilitou a Ariano Suassuna e a Antero Savedra a execução de suas ilumiaras, e como essas marcas se fazem presentes a partir das aulas-espetáculo de um e das aulas-espetaculosas do outro e de todos os elementos que contribuíram para a criação desses inúmeros aqui-eu-agora sem margens entre realidade e ficção de que é formado o Romance de Dom Pantero no Palco dos Pecadores.

\section{As aulas-espetáculo de Ariano Suassuna, as aulas espetaculosas de Antero Savedra}

A este ponto, apresentados os "A.S." do livro e algumas de suas máscaras, já deve estar bastante claro que as margens entre a vida de Ariano Suassuna e o seu fazer artístico não podem ser facilmente delimitadas. Deixemos explícito que de maneira nenhuma demarcar esses limites é um dos nossos objetivos. A própria união entre os planos do real e da ficção é característica do ser performativo que Suassuna se tornou.

Diana Klinger, em artigo publicado em 2008, reflete sobre as relações entre a escrita de si e a performance em produções literárias contemporâneas, partindo "da hipótese de que a autoficção se inscreve no coração do paradoxo deste final de século $X X$ : entre um desejo narcisista de falar de si e o reconhecimento da impossibilidade de exprimir uma 'verdade' na escrita" (KLINGER, 2008, pp. 18-19). A partir da teoria da performance de gênero, de Judith Butler, a autora afirma que na autoficção, diferentemente do caso da autobiografia, não se parte da ideia de um sujeito "modelo" "não existe original e cópia, apenas construção simultânea (no texto e na vida) de uma 

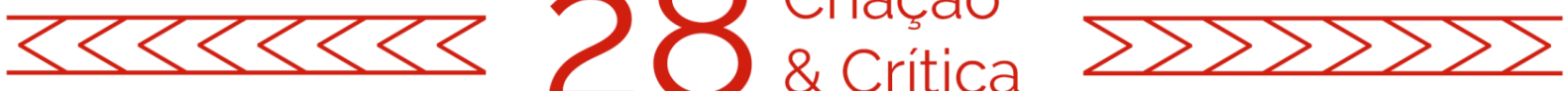

figura teatral - que é o autor" (KLINGER, 2008, p.20).

O próprio mecanismo desse texto autoficcional é performático. No caso do romance que aqui comentamos, a figura teatral resultante da escrita autoficcional de Suassuna é o Dom Pantero. Antero e Ariano, ao usarem essa mesma máscara, garantem essa construção simultânea de que fala o trecho transcrito anteriormente.

Nesta seção do trabalho, trataremos das aulas-espetáculo de Suassuna, que são também, claro, as aulas-espetaculosas de Savedra e que são peça chave para A Ilumiara, mas também para a criação dessa figura do autor pela presença em palco. O Dom Pantero do palco das aulas foi se aproximando do Dom Pantero da narrativa: "o texto autoficcional implica uma dramatização de si que supõe, da mesma maneira que ocorre no palco teatral, um sujeito duplo, ao mesmo tempo real e fictício, pessoa (ator) e personagem" (KLINGER, 2008, p. 25).

Para divulgar as ideais do Movimento Armorial, que idealizou e cujo lançamento foi em 18 de outubro de 1970, Suassuna começou a desenvolver um modelo de palestra acompanhada de música e de dança, que nomeou de aula-espetáculo. Como professor da Universidade Federal de Pernambuco, cargo que exerceu por 32 anos, já demonstrava grande talento como orador. Apesar de nunca realizar verificações de presenças, suas salas estavam sempre lotadas, muitas vezes por alunos que nem estavam matriculados.

Durante sua já referida atuação como secretário de cultura de Pernambuco no governo de Miguel Arraes, Suassuna desenvolveu as aulas-espetáculo em três tipos de apresentações diferentes: a "completa", em que se apresentava acompanhado de músicos e dançarinos; a "reduzida", em que contava apenas com a presença de músicos, por vezes apenas Antônio José Madureira; e a "reduzidíssima", em que apenas Suassuna subia ao palco. Adriana Victor, jornalista que acompanhou Suassuna em seu trabalho durante anos, assim descreve o que ele fazia nessas apresentações:

Ariano nunca levou texto pronto para as aulas - tudo, ou quase tudo, vem de improviso, como um cantador nordestino puxando versos de memória e da força criadora. O que importou sempre, segundo ele, foi discutir a situação da cultura brasileira. E assim segue "versando".(...) Ao final de mais de duas horas de espetáculo, encanta as plateias, que invariavelmente o presenteiam com uma salva de palmas. (VICTOR; LINS, 2007, p. 117)

O encantamento das plateias era uma constante em qualquer lugar do Brasil. Suassuna fez aulas completas, reduzidas e reduzidíssimas em teatros, escolas, universidades, praças públicas de todos os estados do país. A recepção do público era sempre calorosa, emocionada. Em alguns momentos, se confundia com devoção: houve episódios de pedidos de bênção em crianças, e um que ele adorava contar, que uma pessoa pediu uma receita para parar de roer unha. A presença no palco garantia a produção de um momento de troca e de potência de tudo o que ele defendia, de como enxergava os caminhos para a cultura brasileira. Foi nessas aulas que ele levou com mais empenho aquilo que considerava como missão.

Suassuna dizia que, para ele, arte não era produto de mercado. "Podem me 

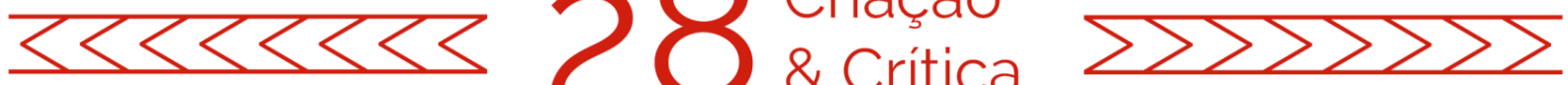

chamar de ingênuo", repetia, "mas arte, para mim, é missão, vocação e festa". Produziu em muitas modalidades artísticas e para aquelas nas quais não atuou, apontou caminhos. Criou uma verdadeira Poética e, nas aulas-espetáculo, articulava os elementos que a compunham de maneira magistral.

Entre 2007 e 2014, durante no governo de Eduardo Campos, Suassuna voltou, naquele momento já com 80 anos, a exercer o cargo de secretário de cultura do estado de Pernambuco. Nesse período, as aulas-espetáculo alcançaram o formato que de maneira mais completa promovia a realização dos sonhos de Dom Pantero. Como assessores da secretaria, Suassuna nomeou artistas populares, músicos, dançarinos (como, ressaltam Victor e Lins (2007), aliás, já havia feito durante o governo Arraes) e com eles montou o "Circo da Onça Malhada", realizando, segundo dizia em todas as aulas, o sonho antigo, de menino, de ser dono de circo.

Inspirado pelos nobres temas do Palco e da Estrada, o Circo da Onça Malhada passou por 98 cidades do estado, nas quais foram executadas 165 aulas-espetáculo. $O$ público total estimado foi de 160 mil pessoas, com média de 970 pessoas por apresentação. Eram aulas do tipo "completo", com músicos, cantores e bailarinos. O circo possuía cenário e figurinos pintados por Manuel Dantas Vilar Suassuna, filho do escritor.

Apesar do improviso já citado, as aulas do Circo da Onça Malhada foram estruturadas a partir de temáticas específicas. Na primeira delas, "Nau", Suassuna falava sobre as raízes da cultura brasileira, com exemplos de músicas e danças representativas das raízes indígenas, africanas e ibéricas. A segunda, "Tributo a Capiba", era uma homenagem ao grande compositor pernambucano Lourenço da Fonseca Barbosa. No ano de encantamento de Suassuna, a trupe foi a Taperoá homenageá-lo. O jornalista Mateus Araújo assim descreveu o espetáculo:

No final da noite, o Circo da Onça Malhada voltou a erguer sua lona de magia e beleza. Desta vez, sem o mestre. Emocionados, o grupo de músicos e bailarinos fizeram uma apresentação especial na praça João Suassuna, no centro, onde relembram trechos das aulas-espetáculo Nau e Tributo a Capiba. (...) Entre os passos de Maria Paula Costa Rêgo, Jáflis Nascimento, Mestre Meia-Noite e Pedrinho Salustiano, e em meio à melodia dos músicos regidos pelo maestro Antônio Madureira (que conduziu a aula) e das vozes de Isaar França e Ednaldo Cosmo, lá estava Ariano, de novo, onipresente no seu circo que pela primeira vez chegou à sua terra". (ARAÚJO, 2014)

No palco, estavam as soluções para a síntese almejada. No trecho de Adriana Victor (2007) que transcrevemos anteriormente, ela compara Suassuna aos cantadores do Nordeste, no que trazem de improviso. Acreditamos que havia também, nas apresentações de Suassuna, aproximações com os contadores de histórias nordestinos. Falaremos disso com mais detalhe adiante, mas grande parte do encanto do público que o ouvia vinha da enorme habilidade que o escritor tinha em contar histórias. Ele costurava riso e emoção de maneira envolvente, dando voltas mas sem perder o eixo central do que buscava dizer. Vídeos que contém trechos de aulas-espetáculo chegam a ter milhões de 

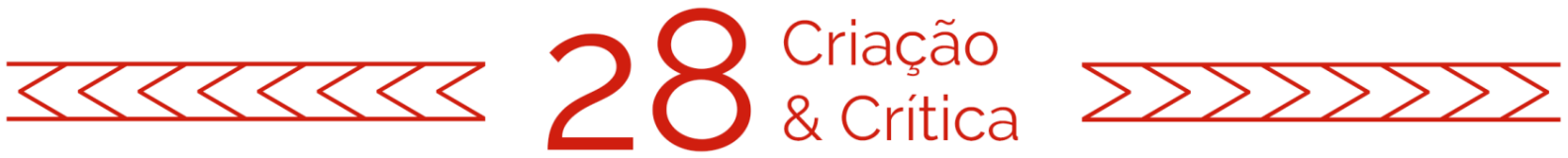

visualizações no youtube, e as histórias ali contadas são conhecidas do grande público, passaram a integrar o acervo popular.

\section{A performance como caminho para A llumiara}

Acreditamos que o contar sertanejo é a grande fonte de onde Suassuna e Savedra conseguiram tirar a solução para as suas ilumiaras. Como já dissemos, foi na máscara de Dom Pantero, no existir no palco diante de plateia ouvinte, atenta, enfeitiçada, que Antero Savedra encontrou a solução para a execução de sua Grande Obra. Parte desse encanto do público talvez seja atribuída a uma promessa que fez a um santo:

\section{DOM PANTERO}

(...) nos dias que precederam imediatamente a Viagem, ainda me restava um impedimento para levar adiante as Aulas-Espetaculosas: continuava a ter medo do Palco e precisava de uma garantia de sucesso perante o Público; especialmente, por ser um Velho, diante dos Jovens que por acaso fossem ao Teatro.

Aí fiz uma promessa a São Cipriano para que, começando pela primeira, as Saídas e as Aulas-Espetaculosas se transformassem em êxitos indiscutíveis e retumbantes. Escolhera aquele Santo porque, segundo relatos de sua Vida, ele encantava e seduzia os Jovens de seu tempo; principalmente as Moças, como consta d'O Grande e Verdadeiro Livro de São Cipriano e a Bruxa Lagardona. (SUASSUNA, 2017b, p. 101)

Fruto de feitiço ou não, foram as aulas espetaculosas que possibilitaram a síntese das obras familiares que ele buscava. É, portanto, através da união de duas figuras performáticas, o Palhaço e o Professor, que se traça o caminho d'A llumiara. Dessa forma, a compreensão e o aprofundamento da ideia de performance nos parecem essenciais para o aprofundamento do estudo sobre o romance de Suassuna.

Fazendo um contraponto com o termo recepção, que define inicialmente como um "termo de compreensão histórica, que designa um processo, implicando, pois, a consideração de uma duração", Paul Zumthor, em seu livro Performance, recepção, leitura, afirma:

A performance é outra coisa. Termo antropológico e não histórico, relativo, por um lado, às condições de expressão, e da percepção, por outro, performance designa um ato de comunicação como tal; refere-se a um momento tomado como presente. A palavra significa a presença concreta de participantes implicados nesse ato de maneira imediata. (ZUMTHOR, 2014, p. 51)

A Zumthor, no que diz respeito das relações entre o texto literário (que chama de texto poético) e a performance, interessam as implicações de um sujeito leitor que é corpo. A materialidade da voz e o campo dêitico particular que o contato com o texto poético cria em "um aqui-eu-agora jamais exatamente reproduzível" (ZUMTHOR, 2014, p. 57). 

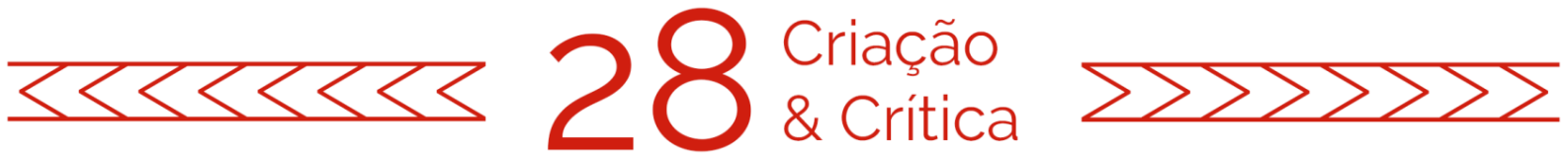

Neste trabalho, interessa-nos este aqui-eu-agora criado pelas aulas-espetáculo de Suassuna em consonância com o seu público - no país inteiro, sempre bem recebido, plateias enormes e envolvidas -, mas também o momento de presença que resulta da leitura do livro que estudamos e a fusão proposital que há entre autor e personagens.

O leitor que mergulha no Romance de Dom Pantero no Palco dos Pecadores deixa seu corpo ser afetado pela obra testemunho e testamento de Suassuna, ou da figura dessa autor que chamamos de Ariano Suassuna, mas que foi se construindo como suporte para o Pantero e outras máscaras, tudo potencializado pelo existir em um Palco (real ou construído em literatura). Na escrita performática de Suassuna, "a figura do autor e do narrador se potencializam no gesto alegórico que é, sempre, um movimento de leitura" (RAVETTI, 2002, p. 55). Esse romance é a síntese de tudo o que o escritor fez, de tudo o que ele foi e quis ser, rumo a eternidade. Esse é um livro pautado pelo desejo de permanência e se constrói todo de presença. É uma performance de si em si.

A voz é o chamado primeiro dessa presença, que se anuncia desde o começo pautada no diálogo. Como no texto teatral, o diálogo proposto por Dom Pantero se propõe potência a ser vivida em palco, jogo duplo de texto: "O poema assim se "joga": em cena (é a performance) ou no interior de um corpo e de um espírito (a leitura)" (ZUMTHOR, 2014, p.61).

No contato do leitor com Dom Pantero, a voz é marcante: todos os poemas citados aparecem sem a separação dos versos. No exemplo a seguir, vemos um soneto transcrito tal como no livro. A configuração do texto traz a leitura a um momento de performance de voz e de ouvir, pois o escritor sugere a declamação acompanhada por uma música:

PARA ELISA

Soneto (com Estrambote-alexandrino reiterativo.

A ser recitado ao som de "Für Elise", de Bethoven)

\section{ADRIEL SOARES}

Oh Romã-do-pomar, relva, esmeralda, olhos de ouro e de azul minha Alazã! Ária em corda do Sol, fruto de prata, meu Chão e meu Anel luz da Manhã!

Oh meu sono, meu sangue, Dom, coragem, Água das pedras Rosa e Belveder! Meu Candieiro aceso da Miragem, meu Mito e meu poder minha Mulher!

Dizem que tudo passa e o Tempo duro tudo esfarela: o Sangue há de morrer! Mas quando a luz me diz que este Ouro puro se acaba por finar e corromper, meu Sangue ferve, contra a Maldição, que há de pulsar Amor na escuridão,

- pulsar o nosso Amor até na Escuridão! (SUASSUNA, 2017b, p. 46).

De maneira informal, Suassuna justificava essa apresentação como uma tentativa de diminuir o número de páginas, já que o livro é bastante extenso. O autor dizia acreditar que "o leitor de poesia" reconheceria os versos ali apresentados. O "leitor de poesia" precisa, 

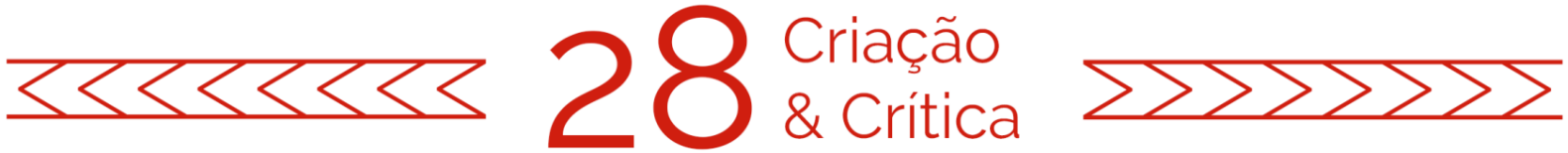

portanto, sentir em sua voz, no ritmo que aquelas palavras impõem, onde estão os versos do texto. O livro é todo voz, todo diálogo. $\mathrm{E}$, em sua representação física, é também um convite ao aqui-eu-agora da performance, a partir de seus elementos gráficos:

Daí a formação de caligrafias, fenômeno universal, como um esforço último para reintegrar a leitura no esquema da performance, fazer dela uma ação performancial. O que é, com efeito, caligrafar? É recriar um objeto de forma que o olho não somente leia, mas olhe; é encontrar, na visão da leitura, o olhar e as sensações múltiplas que se ligam a seu exercício. (ZUMTHOR, 2014, pp. 71-72).

Seguindo uma linha de experimentos que começa na ilustração do Romance d'A Pedra do Reino (1971) e continua no aprofundamento que foi a experiência das iluminogravuras (1980/1985), Suassuna ilustrou todas as páginas do livro novo. Além disso, utiliza dois tipos de caligrafia, os dois alfabetos que criou.

O primeiro, baseado nos ferros de marcar sertanejos, já é bem conhecido pelo público e se chama alfabeto sertanejo. Os designers Ricardo Gouveia de Melo e Giovana Caldas criaram, a partir dele, uma fonte de computador que chamaram de Armorial e hoje está presente em quase toda publicidade ou texto de apresentação relacionados ao próprio Suassuna ou ao Movimento Armorial. Por escolha de Suassuna, essa tipografia aparece em diversos momentos do romance, seja para anunciar quem fala, seja para marcar com diferença alguns termos que lhe são caros (estratégia que pode ser comparada ao uso de maiúsculas feito pelo escritor em seus poemas e textos em prosa).

O segundo alfabeto é usado principalmente nas imagens das vinhetas das páginas do livro e tem como base de inspiração a arte rupestre brasileira. Como sempre, Suassuna fez questão de representar os três elementos que considera os formadores daquilo que hoje entendemos como a cultura brasileira: a arte rupestre, a arte barroca e a arte popular.

Para além do objeto livro, no entanto, interessa-nos a performance espetáculo, o tema do palco. Ariano Suassuna partilhava com Antero Savedra a performatividade do contar. A família Suassuna tem vários contadores de histórias, Ariano não era considerado nem o melhor entre eles. Como já afirmamos, os vídeos que mostram trechos de suas aulas-espetáculo chegam a ter um milhão de visualizações no youtube. Há algo de ancestral no fascínio, na identificação e no riso que provocam:

Eu e os meus irmãos herdamos de nosso Pai, João Suassuna, entre outras coisas, o amor pelo Romanceiro Popular do Nordeste e o gosto de contar histórias. Uma vez, conversando com Manuel Benício - um dos homens mais corajosos que a Paraíba já viu - ele me disse: - "A conversa de seu Pai era um olho d'água. A gente passava horas ouvindo, e quando ele queria esbarrar a reclamação era geral".

Acho que nós, filhos dele, concordamos numa opinião: de todos, o terceiro, Lucas, foi o que mais puxou ao Pai, nisso, pois sua conversa e suas histórias formavam, também, um verdadeiro espetáculo. (SUASSUNA, 2003, p.11) 

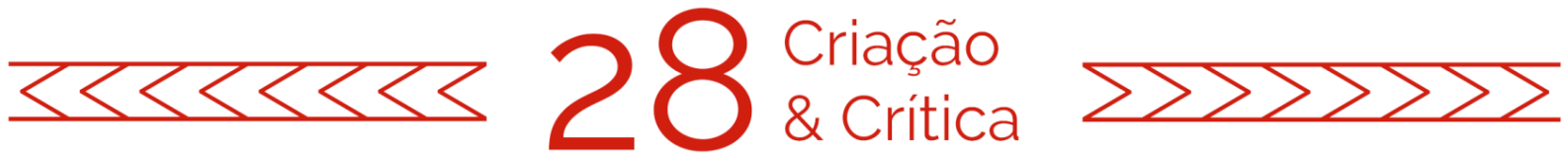

Foi a herança desse contar que uniu Suassuna tão fortemente ao seu público. Provavelmente não houve outro escritor brasileiro tão celebrado em vida pela população brasileira. O riso e a identificação eram lei em qualquer apresentação que fez no país inteiro, das capitais às cidades mais interioranas.

Uma das coisas que o lançamento do Romance de Dom Pantero no Palco dos Pecadores revelou foi que Ariano Suassuna, como Antero Savedra, vestia a máscara de Dom Pantero em apresentações públicas. Nada em sua vida era completamente desconectado do seu fazer artístico, nem das suas crenças. Agia e terminava sendo percebido como o que Diana Klinger descreve no trecho a seguir: "o autor é considerado como sujeito de uma performance, de uma atuação, que "representa um papel" na própria "vida real", na sua exposição pública, em suas múltiplas falas de si, nas entrevistas, nas crônicas e auto-retratos, nas palestras" (KLINGER, 2008, p. 24).

O jeito que se vestia, por exemplo, seguia um propósito. Já sabíamos disso porque sempre falava em entrevistas, por exemplo, do impacto que lhe causou a leitura, em 1981, de um artigo escrito por Gandhi:

Eu lera, de Gandhi, uma frase que me impressionou profundamente. Dizia ele que um indiano verdadeiro e sincero, mas pertencente a uma das classes mais poderosas de seu país, não deveria nunca vestir uma roupa feita pelos ingleses. Primeiro, porque estaria se acumpliciando com os invasores. Depois, porque, com isso, tiraria das mulheres pobres da Índia um dos poucos mercados de trabalho que ainda lhes restavam. A partir daí, passei a usar somente roupas feitas por uma costureira popular, Edite Minervina (SUASSUNA, 2000)

Só usava as roupas feitas por Edite e abandonou também o uso da gravata. Edite costurava conjuntos de calça e paletó de linho em poucas variantes de cores: mescla azul, branco, e cáqui, e camisas de popeline apenas brancas. Um tempo depois, o escritor foi convidado para um evento no qual receberia a Medalha do Infante Dom Henrique na presença do então Presidente de Portugal, Mário Soares.

O convite que recebeu exigia o traje "Esporte Fino". Suassuna encomendou então a Edite a sua versão um pouco provocativa da roupa exigida: com o paletó e a calça pretos e a camisa vermelha, apelidou o conjunto de "Sport fino". A parte "fina" seria o uso do preto, e a cor vermelha garantia a parte "Sport" do traje, homenageando o seu time do coração, o Sport Club do Recife, cujo padrão é rubronegro. Em um vídeo de uma aula-espetáculo em que explicava tudo isso (Disponível em: https://www.youtube.com/watch?v=1k078e4mA98), Suassuna afirma que, quando imagina que estará diante de um público "fino", veste essas cores para homenageá-lo.

Esses posicionamentos e escolhas políticas expressos na vestimenta, portanto, já eram bastante conhecidos do público de Suassuna. O que só se revelou após o lançamento do romance novo é que a escolha das cores usadas em cada ocasião apontava a máscara que o escritor escolhera usar a cada vez: 

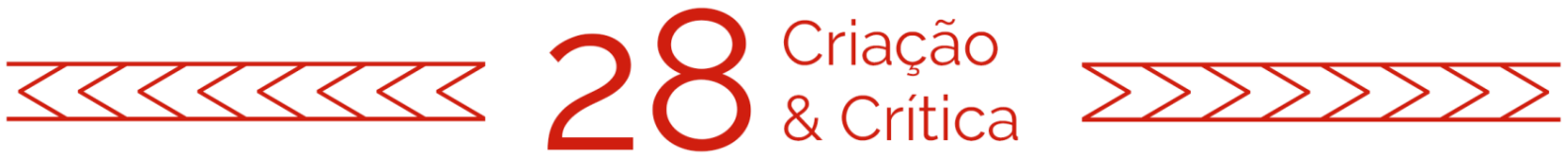

\section{DOM PORFÍRIO DE ALBUQUERQUE}

(...) o nosso Mestre passou a vestir-se de dois modos: de roupa clara, quando encarna Antero Savedra, e de negro-e-vermelho quando representa Dom Paribo Sallemas ou Dom Pantero (sendo que, neste último caso, pendura um Medalhão ao pescoço). E foi com essas roupas que ele, conduzindo sua trupe de Músicos, Atores, Bailarinos e Cantores, passou a empreender suas Saídas pelos palcos, estradas e descaminhos do Mundo - no caso dele representado pelo Brasil (porque sempre sustentou que, sendo o Ser-humano o mesmo em todos os lugares e em todos os tempos, se ele representasse bem o Brasil estaria representando bem o Mundo inteiro, pois "o Brasil é o Sertão do Mundo"). (SUASSUNA, 2017b, pp. 52-53)

Revela-se, portanto, pela primeira vez, um novo Ariano: multifacetado, polifônico e que, na verdade, vivia uma via de mão dupla: a literatura influenciada pela vida, e a vida transformada pela literatura. Aliás, onde estariam as margens que as dividem?

O modo de se vestir é apenas um dos muitos gestos performáticos em que passa a corporificar a própria literatura. O cotidiano de Suassuna, sua vida familiar e também as suas apresentações públicas eram, portanto, permeados pela ideia de performance:

(...) se os artistas buscam na idéia de performance a superação da dicotomia arte-vida é porque se inspiram nas próprias situações do cotidiano. Relações tais como a de um advogado num tribunal, de um professor numa sala de aula, ou de um político diante de sua audiência são performáticas, da mesma forma que um rito religioso ou um espetáculo esportivo. A maneira de se vestir e de se apresentar publicamente, o conjunto de gestos e expressões faciais de um grupo social, práticas de etiqueta - todo um enorme universo que nos circunda no dia-a-dia é de caráter performático (LOPES, 1994, p.3)

Se a leitura de suas obras já aponta para a necessidade de vê-las como conjunto uno, obra de arte total, não se deve excluir desse princípio de totalidade a própria atuação pública de Suassuna, e mesmo escolhas que fez em sua vida privada. Na leitura do Romance de Dom Pantero, o gesto performático não tem como ser ignorado: "a escrita de si como performance também supõe uma revisão na noção de valor literário: a autoficção não pode ser lida apenas a partir das qualidades estéticas do texto. A autoficção só faz sentido se lida como show, como espetáculo, ou como gesto." (KLINGER, 2008, p.24).

No romance que aqui discutimos, há citações de seu fazer artístico em todas as modalidades em que criou, há referências íntimas de sua vida familiar, de suas reflexões e questões religiosas, discussões públicas com outros intelectuais. Tudo é arte, tudo faz parte de sua missão, de seu propósito:

"na ideia do performático, tanto no teatro, na literatura, como na arte em geral, parece coexistir a vontade de ultrapassar os limites dos suportes tradicionais - físicos e simbólicos - e a de abraçar o compromisso da obra em aberto, work in progress, sob as premissas de que tudo é arte e tudo é 

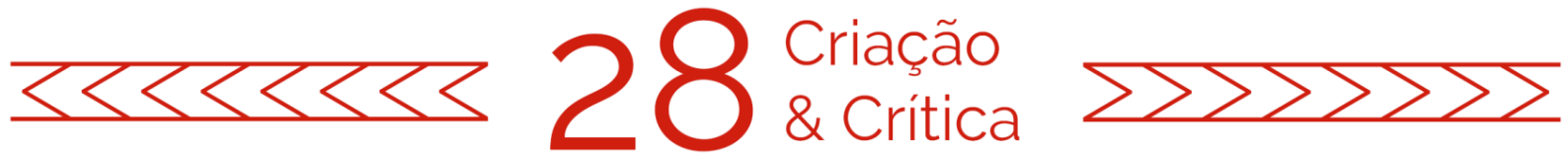

vida. O tema obsessivo do peformer é o de se propor como veículo para a representação das transformações corpóreas e incorpóreas dos corpos em sociedade." (RAVETTI, 2002, pp. 65-66 )

Se é a performance que garante o formato possível da síntese almejada para a realização da obra de arte total, é a máscara de Dom Pantero que permite, ao final, a ascensão do escritor ao plano imortal da arte e do sagrado. Ao fundir-se em personagem, o poeta escapa do horror de uma existência feia, sombria e finita:

\section{ANTERO SAVEDRA}

Sim, porque aquela Visão era também uma Sagração e foi ela que me permitiu escrever estas cartas com a paixão que meu assunto exigia: mesmo continuando a ser o Antero Savedra sombrio, culposo e feio do dia a dia, a Visão, ao fundir-me à máscara-e-persona de Dom Pantero, fizera de mim um Personagem, mais uma vez possuído pelo Dáimone, "um Rei imortal, transfigurado em Poeta, Palhaço e Profeta" (SUASSUNA, 2017b, p.79).

Foi o encantamento de Suassuna e a subsequente publicação do Dom Pantero que permitiram a compreensão da presença dessas máscaras todas em seu contar.

\section{Conclusão - o pacto para não haver fim}

Ao escolher fundir-se com a máscara de Dom Pantero, Suassuna nega a própria morte. Acreditamos que a escrita do seu último romance se fez tão longa porque havia, no escritor, de maneira mais íntima, uma resistência em declarar concluída a obra de sua vida. Provavelmente um misto entre o medo de não conseguir concluí-la e o de concluí-la e então findar também o que de vida ali se atrelava. O problema da morte é recorrente em narrativas performáticas:

Em quem escreve como performer, o corpo se impõe, nos jogos com a subjetividade e a biografia, a exposição das marcas da vida pessoal (o sexo, a tortura, os territórios ocupados, os medos, as traições) e, sobretudo, pela interseção com a morte, no esforço repetido de recuperar a si mesmo em suas partes, inscrito em algum esquema coletivo e de tempos recuperados (RAVETTI, 2002, pp. 61-62).

Em certo momento, o escritor dizia ter feito um pacto com Deus. O tal pacto encontra-se descrito e explicado na voz de Dom Pantero ao final do primeiro volume do romance. No trecho transcrito abaixo, note-se, além do referido pacto, a audácia de Antero Savedra que, ao apresentar em seu diálogo contribuições do mais variados autores, apresenta-os, todos, como membros de sua família:

\section{DOM PANTERO}

Aí, fiz uma espécie de pacto com Deus: se Ele achasse que a tarefa que eu ousava levar adiante era sacrílega, que a interrompesse pela Morte 

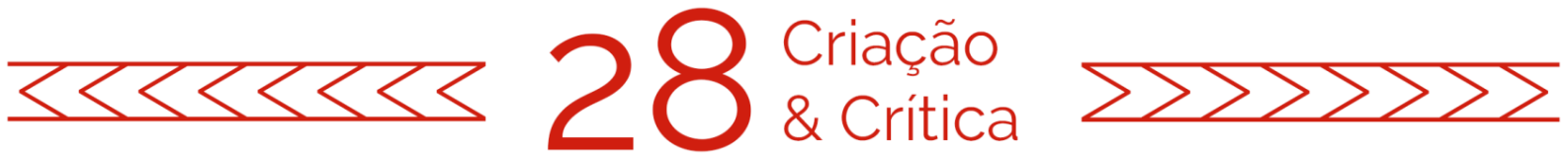

- sentença com a qual desde ali me declarava de acordo.

Como, afinal, cheguei até aqui, considerei tal fato como uma concessão (provavelmente d'Ele obtida pela Misericordiosa). Entenda-se: minhas preocupações eram religiosas; porque, do ponto de vista da Arte, tinha a convicção de que aos poucos estava realizando "o Poema, o sagrado, o que importa"; de modo que me sentia também autorizado a pedir, como o Poeta:

\section{MANUEL BANDEIRA HÖLDERLIN DE SAVEDRA}

"Mais um Verão, mais um Outono, oh Parcas, para amadurecimento do meu Canto, peço que me concedais: então, saciado do doce Jogo, o coração me morra. (SUASSUNA, 2017b, pp. 469-470)

O próprio formato do livro revela uma estratégia do autor para garantir que concluiria o seu projeto. Cada uma das cartas que compõem o romance termina da mesma maneira, com os mesmo versos ${ }^{3}$, em uma "Doxologia". Assim, o livro poderia ter sido terminado com uma quantidade menor ou maior de cartas, a depender da Misericordiosa e da sua parte firmada no pacto com Deus.

Até nisso, o Dom Pantero é um romance que se aproxima do fazer performático: "a obra de autoficção também é comparável à arte da performance na medida em que ambos se apresentam como textos inacabados, improvisados, work in progress, como se o leitor assistisse 'ao vivo' ao processo da escrita” (KLINGER, 2008, p. 26).

Felizmente, a concessão da Compadecida se estendeu até o final do segundo volume, e só terminou quando o poeta anunciou o fim do projeto e o saciar de seu doce jogo, semanas antes de seu encantamento.

Em verdade, devemos dizer: fossem mais dois, dez, quinze anos de concessão, teriam sido mais cartas, mais volumes, mais saídas de Dom Pantero. Em 2013, um infarto debilitou a saúde de Suassuna, até então praticamente infalível, forçando-o a dar unidade ao que havia feito até então, para garantir o final de seu projeto. $O$ final ao qual chegou antes de sua despedida é um entre os muitos que poderiam ter existido, por quanto tempo seu tempo tivesse se prolongado.

Além de mais tempo, Dom Pantero pediu a Deus que lhe concedesse um encontro digno com Caetana, no único lugar em que sua existência era possível. Houve grande misericórdia, e tudo aquilo que foi requisitado terminou sendo atendido, pois, no dia 18 de julho de 2014, pela última vez, Dom Pantero pegou a Estrada e subiu ao Palco vestido de

\footnotetext{
${ }^{3}$ Aqui estão os versos compostos em martelo-gabinete e martelo-agalopado que concluem a "Doxologia" de cada carta de Dom Pantero: "O Circo: sua Estrada e o Sol de fogo. Ferido pela Faca, na passagem, meu Coração suspira sua dor, entre os cardos e as pedras da Pastagem. O galope do Sonho, o Riso doido, e late o Cão por trás desta Viagem.

Pois é assim: meu Circo pela Estrada. Dois Emblemas Ihe servem de Estandarte: no Sertão, o Arraial do Bacamarte; na Cidade, a Favela-Consagrada. Dentro do Circo, a Vida, Onça-malhada, ao luzir, no Teatro, o pelo belo, transforma-se num Sonho - Palco e Prelo. E é ao som deste Canto, na garganta, que a cortina do Circo se levanta, para mostrar meu Povo e seu Castelo." (SUASSUNA, 2017, pp. 118-119)
} 

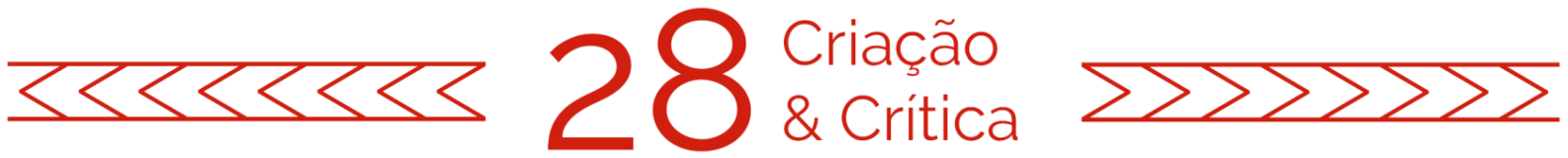

Sport Fino no Festival de Inverno de Garanhuns, despedindo-se de seu público em uma bela e marcante aula espetaculosa, em tributo ao seu querido amigo Capiba 4 .

\section{Referências}

ARAÚJO, Mateus. Ariano Suassuna é um Sertão perene. Jornal do Commercio. 14/12/2014. Recife, PE. Disponível em: https://jc.ne10.uol.com.br/canal/suplementos/jcmais/noticia/2014/12/14/ariano-suassuna-e-um-sertao-perene-160406.php. Acesso em 23 jul 2020.

AZEVEDO, Luciene. Autoria e performance. Revista das Letras, São Paulo, 47(2): 133158, jul.dez. 2007.

CAMPELO FILHO, Brivaldo; CARRERO, Raimundo; DA FONTE, Carlos; SUASSUNA, Ariano. Projeto Cultural Pernambuco - Brasil. Recife: Companhia Editora de Pernambuco, 1995.

GUIMARÃES ROSA, João. Discurso de posse na Academia Brasileira de Letras (ABL). 1967. Disponível em: http://www.elfikurten.com.br/2011/02/guimaraes-rosa-discurso-deposse-na.html. Acesso em 08 dez 2020.

KLINGER, Diana. Escrita de si como performance. Revista Brasileira de Literatura Comparada, Niterói, v.10, n.12: 11-30, 2008.

LOPES, Antonio Herculano. Performance e história (ou como a onça, de um salto, foi ao Rio do princípio do século e ainda voltou para contar a história). Rio de Janeiro: Fundação Casa de Rui Barbosa, 1994.

NEWTON JÚNIOR, Carlos. A construção da 'obra total' de Ariano Suassuna. Folha de São Paulo. 17/08/2014. São Paulo, SP. Disponível em: https://www1 folha.uol.com.br/ilustrissima/2014/08/1500705-a-construcao-da-obra-totalde-ariano-suassuna.shtml. Acesso em 23 jul 2020.

Dom Pantero e sua llumiara. In: SUASSUNA, Ariano. Romance de Dom Pantero no Palco dos Pecadores. Rio de Janeiro: Nova Fronteira, 2017. pp. 11-19.

RAVETTI, G. Narrativas performáticas. In: RAVETTI, G.; ARBEX, M. (Org.). Performance, exílio, fronteiras: errâncias territoriais e textuais. Belo Horizonte: Departamento de Letras Românicas UFMG, 2002.

SUASSUNA, Ariano. Mocinha. Folha de São Paulo. 27/06/2000. São Paulo, SP. Disponível em: https://www1.folha.uol.com.br/fsp/opiniao/fz2706200006.htm. Acesso em 23 jul 2020.

Prefácio. In: SUASSUNA FILHO, João. Outras memórias e histórias. Recife: Ed. do autor, 2003.

\footnotetext{
${ }^{4}$ Essa aula ficou registrada em notícias de jornal, por exemplo, em: ÚLTIMA aula-espetáculo de Ariano Suassuna lotou teatro. Correio Braziliense, Brasília, 23/07/2014. Disponível em: https://www.correiobraziliense.com.br/app/noticia/brasil/2014/07/23/interna-brasil,438825/ultima-aulaespetaculo-de-ariano-suassuna-lotou-teatro.shtml. Acesso em 09 dez. 2020.
} 

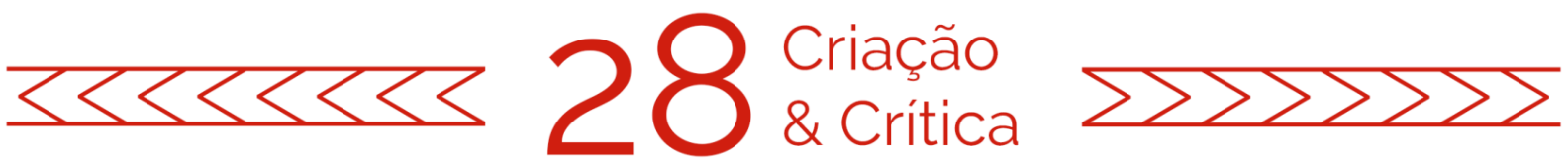

Romance d'A Pedra do Reino e o Príncipe do Sangue do Vai-e-Volta. Rio de Janeiro: Nova Fronteira, 2017a.

Romance de Dom Pantero no Palco dos Pecadores. Rio de Janeiro: Nova Fronteira, 2017b.

. Yaari - diálogo sobre a llumiara Brennand. In:

Almanaque Armorial.

Recife: Editora José Olympio, 2008b. p. 249-264.

VICTOR, Adriana; LINS, Juliana. Ariano Suassuna: um perfil biográfico. Rio de Janeiro: Jorge Zahar Ed., 2007.

ZUMTHOR, Paul. Performance, recepção, leitura. São Paulo: Cosac Naify, 2014.

Recebido em: 24/07/2020 Aceito em: 08/11/2020

Referência eletrônica: SUASSUNA SIMÕES, Ester. O Palco e a Estrada: o lugar da performance no "Romance de Dom Pantero no Palco dos Pecadores", de Ariano Suassuna. Criação \& Crítica, n. 28, p., dez. 2020. Disponível em: $<$ http://revistas.usp.br/criacaoecritica>. Acesso em: dd mmm. aaaa. 